\title{
Towards Responsible Management Education: A Transformational Model
}

\section{Stephen Yong-Seung Park}

School of Management, Kyung Hee University, Seoul, Korea

Objectives: Although literature on the meaning and practice of responsible management education (RME) has recently been increasing in the field of business research, most of the literature is limited to a partial viewpoint, and a systematic approach to integrate related variables into a coherent context has been a rarity. This study presents a transformational model that integrates how to systematically approach a paradigm change of RME in business schools.

Methods: After conducting a review of the literature on RME, this paper provides a transformational model for an integrated and systematic approach towards a successful paradigm shift in business education. The model consists of three inter-connected components: people (i.e., professors), pedagogy, and institutions (i.e., business schools).

Results: Through the integrated transformational model, three interconnected components are described for the full implementation of the new paradigm in business education. This study proposes a dynamic relationship between each component and a successful paradigm change in management education.

Conclusions: The new management education paradigm change based on the principles of RME has become a matter of practice, not a matter of choice. There are technological aspects such as the management of business schools as an organization and teaching methodologies for successful change management in business education, but what is more important is the matter of the consciousness of professors. It is time to reflect upon the ontological purpose of teaching as a business professor and to recuperate a sense of calling.

Key Words: Responsible Management, Responsible Management Education, Business School, Corporate Social Responsibility, Business Ethics

\section{Introduction}

Over the past two decades or so, corporate social responsibility (CSR) has attracted major attention in the management paradigm, and it is now no longer a question of whether but how.

Received: May 23, 2018 Revised: Jul 19, 2018 Accepted: Jul 19, 2018

Corresponding author: Stephen Yong-Seung Park

School of Management, Kyung Hee University, 26 Kyungheedae-ro,

Dongdaemun-gu, Seoul 02447, Korea

Tel: +82-2-961-0777, E-mail: yspark@khu.ac.kr

This is an Open Access article distributed under the terms of the Creative Commons Attribution Non-Commercial License (http://creativecommons.org/licenses/ by-nc/4.0/) which permits unrestricted non-commercial use, distribution, and reproduction in any medium, provided the original work is properly cited.

Copyright $\odot 2018$ Korean Association for Business Communication.
For many companies, however, CSR still just means adding another tactic to their public relations effort rather than a serious change in their relationships with society. In order to make the ongoing CSR movement both authentic and strategically meaningful and effective, both researchers and practitioners of contemporary business ought to realize that companies are managed for the benefit of all of the stakeholders (e.g., their employees, customers, government, community, and environment) in their ecosystem, not just shareholders. This stakeholder management paradigm represents a major shift from the traditional shareholder management paradigm. It is indeed a transcendental level of change in the management paradigm for business corporations today (Mackey \& Sisodia, 2013). 
As such, management education in business schools around the world have been going through major changes in their role as responsible educational institutions in a post-modern society (Amann, Pirson, Dierksmeier, Von Kimkowitz, \& Spitzeck, 2011). Like the corporate world, business schools now face the challenge of adopting the newly emerging stakeholder perspective (Gioia, 2002). Successfully managing this paradigm change in business education is most important not only for business schools themselves but also for a sustainable corporate world that will ultimately be led by future graduates of business schools.

Although literature on the meaning and practice of responsible management education (RME) has recently been increasing in business research, most of the literature is limited to a partial viewpoint, and a systematic approach to integrating related variables into a coherent context has been a rarity. In this paper, I propose a transformational model that presents a balanced viewpoint for successful paradigm change management in business education.

This paper will first sketch the general background of RME from the perspective of a post-industrial business environment. Then, a future direction of business education will be suggested following a new framework for education in the future, learning to be' and 'learning to live together' proposed in the UNESCO's future education report (Delors et al., 1996). Finally, a transformational model of RME-composed of people, pedagogy, and institutions-will be suggested.

\section{RME: The Self-Actualization of Business Education}

Business education, which was originally started as a professionalization project for a newly emerging group of professionals called managers in the era of industrialization, is now undergoing a critical turning point in our post-industrial world. For the last two decades, a group of enlightened business thinkers around the world has noted the ineffectual and inadequate status of contemporary business education (Bennis \& O'Toole, 2005; Ghoshal, 2005; Khurana, 2011). Corporate scandals around the world, irresponsible footprints of business operations on the environment, and the social inequality caused by the profit-maximizing model of business further clarify such delinquencies caused by unconscious business while ultimately raising the question of the role that business education ought to play in today's turbulent world (Swanson \& Frederick, 2003).

The primary reason for the ineffectual mode of business education today may boil down to its loss of purpose. Business school education first began in 1881, in the age of moderniza- tion, at the University of Pennsylvania in the United States. As noted in the founding mission of the Wharton School at the University of Pennsylvania, business education was rooted in the educational belief that building responsible character in the newly emerging managers would be critical for the sustainable development of an industrial society (Khurana, 2011). Similar to medical schools and law schools, the development of managerial character with the sense of social obligation in a way consistent with the broader interests of the nation has been at the core of the vision for business schools. This founding spirit of business education has been commonly shared among other business schools in the U.S. such as Dartmouth and Harvard, and later throughout the world (Khurana, 2011; Yang et al., 2011). This spirit, however, has lost its way in the tidal wave of globalization and a neo-liberal world order, where a market-based economy and profit maximization maxim became the unshakable proposition of business education (Khurana, 2011; Spitzeck, 2011).

Reflecting upon the ontological purpose of business school when we discuss a new paradigm in business education, namely RME, is meaningful considering that most attempts being made by business schools still follow an economistic paradigm in approaching business-society relations and do not address the intrinsic value of responsible leadership (Pirson \& Malhotra, 2008; Spitzeck, 2013). Therefore, RME can be considered to be not a new paradigm but rather a self-actualization of business education.

\section{RME in the Era of 'Learning to Be' and 'Learning to Live Together'}

What is the purpose of education for RME in a new era? In order to approach this question, it is helpful to refer to the report on future education published by UNESCO. Two UNESCO reports on future education provide an effective set of learning criteria from which today's RME needs to derive. The first UNESCO report was published in 1972 in the wake of the world-wide international turbulence caused by students and citizens in the 1960's (Faure, 1972), and the second report (Carneiro \& Draxler, 2008; Delors et al., 1996) was the outcome of people's reflections on the seemingly unsustainable process of globalization. Both reports suggest the need for a humanistic and optimistic vision of learning that is to transcend the challenges of the industrial era's economistic mass education.

The purpose of education in the era of industrialization is symbolized by 'learning to do' and 'learning to know. For the fragmented knowledge and manual-driven learning methods in the divided and mechanized work structure of the industrial 
age, a factory-type education method has been suitable. However, as we enter the post-industrial era, the purpose of education has shifted to 'learning to be' and 'learning to live together.' In the post-industrial era where an interconnected ecological environment is the norm and technological breakthroughs are realized regularly, the role of education has been to give meaning to the existence of learners rather than provide simple fragmentary knowledge. Moreover, the construction of a community of human beings (i.e., 'learning to live together') that expresses a meaning of being (i.e., 'learning to be') becomes the ultimate meaning of education.

In this direction of future education suggested by UNESCO, business education will not be an exception. Realizing 'learning to be' and 'learning to live together' in business education is the purpose of RME. Only a self-actualizing business leader will be able to lead a responsible and flourishing company and build an ecologically inter-dependent business community.

How can a new level of management education allow students to orient themselves towards self-realization as conscious business leaders in the context of fragmental knowledge in business? How will students in business schools realize that the reality of corporate management is to pursue the health of interconnected economic ecosystems beyond maximizing profits alone? Ultimately, how will business students realize that self-realizing business leaders will be able to build a good society through their self-realizing companies? These questions are to be answered by professors and students through RME.

The purpose and practice of RME in the context of future education is not at all simple. A tremendous challenge lies ahead of business schools. It will be necessary for the philosophy and methodology of all the aspects of teaching, research methods, and social engagement in business schools to be carried out on a new level.

The emerging educational paradigms of 'learning to be' and 'learning to live together' will require today's business educators and their institutions to face the unprecedented challenge of transformational processes. The transformational model of education and learning for the $21^{\text {st }}$ century can be developed based on three dimensions-people (i.e., professors), pedagogy, and institutions (i.e., business schools).

\section{A Transformational Model}

The paradigm change in management education of business schools will face a challenge comparable to that of the corporate world when it went through the perplexing assignment of embedding the gene of CSR and sustainability into its daily business decisions. Like their business counterparts, business

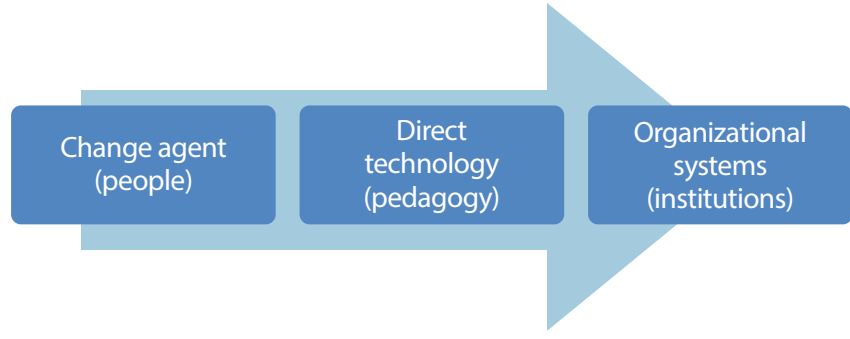

Figure 1. Paradigm change in management education: A transformational model.

schools often regard the challenge, which is to adopt a new way while abandoning the accustomed old way, as the most stimulating (Escudero, 2016; Spitzeck, 2011).

This paper suggests an integrated model for the successful management of transformational change in business education in a more humanistic and responsible direction. I propose a transformational model that includes three major components. Those components are a) the most involved change agent (people) in business education, i.e., professors, b) direct technology through which the purpose of the new paradigm is realized, i.e., pedagogy, and c) the very organizational system of which responsible management itself becomes the actual basis for the sustainable change processes, i.e., institutions (business schools).

\section{People}

The genuine transformation in business education will start with professors. As discussed earlier, the new paradigm in management education in fact is the self-actualization of business schools recalling the founding spirit of the professionalization project in the early days of business education. If the ultimate purpose of business education is to develop a whole-person character in the profession of people called managers, the research and teaching of business professors must be in tune with this perspective of a holistic and integrated approach.

As noted by several enlightened scholars of our time (Freeman \& Newkirk, 2011; Ghoshal, 2005; Hayek, 1974), business professors today ought to be alert to the potential of the pretense of knowledge (Hayek, 1974) and the separation thesis of our research (Freeman \& Newkirk, 2011). In fact, such narrowly defined and segmented expertise equipped with the dominantly positivistic research method so prevalent in business academia today make it easy to produce conveniently manageable research and teaching outcomes separate from practical use and humanistic implications.

Therefore, in order to design and implement change processes in business education in a responsible and humanistic direction, it is inevitable to recuperate the degraded mission of 
business education and business professors. It is the consciousness question of business professors. Their deep reflection upon the ultimate mission of business education and its impact on the integral ecological system of business and broader society will become the basis for an entire transformational process towards a new paradigm in business education.

Based on earlier research done by Gonin (2007), Freeman and Newkirk (2011), and the Community for Responsible Research in Business and Management (2017), I suggest that the following set of questions become the checklist for responsible research of conscious business professors of our time:

-What is the ultimate purpose and value of our research in the business world and society in general?

-What kinds of research agendas are we pursuing? Are the questions meaningful and appropriate?

-What kinds of research modes are we applying? Are there alternative modes of research that could lend insight into these questions?

- Are we inviting relevant stakeholders to the process of designing and conducting our research? Do we opt for sense-making exploration rather than pre-determined hypothesis testing?

-What are the direct consequences of our research?

- Do our research methods have scientific objectivity integrated with the humanistic value of common good and sustainability?

Such a value shift among business professors ought to be accompanied by actions by other relevant stakeholders such as journal editors and publishers, academic association leaders, university deans and senior scholars, accrediting and ranking agencies, funding agencies and government, alumni and students, and colleague scholars (Community for Responsible Research in Business and Management, 2017). While it is true that genuine change cannot be accomplished without a coordinated commitment among relevant stakeholders in the ecosystem of business education (e.g., students, alumni, corporate leaders, NGO leaders, government officials), it is also true that the paradigm shift starts with each professor wakening to her own vision of responsible scholarship.

\section{Pedagogy}

Most criticism against the current practice of business education boils down to its poor pedagogy, which fails to develop a character of responsible business leaders in a post-industrial society (Ghoshal, 2005; Mintzberg, 2004; Silver, 2012). An emphasis on the specialized functional expertise in business, a dominant reliance on scientific analysis in business research and teaching, and an abandonment of soft skills prevailed in business education, which caused narrow-framed worldviews, mistaken assumptions, misguided epistemologies, and poor pedagogies (Kelly \& Nahser, 2014).

The substance of RME does not lie in the development of analytical skills with functional expertise, a mastery of a technical algorithm, or zero-sum-based strategic tactics. Rather, following the original purpose of the professionalization project of the early founding business schools, the foundations of responsible management are nothing more than the character building of responsible and creative business leaders.

Right pedagogy towards the integral human development of future business leaders, therefore, becomes another critical component for the transformational model of RME. Such a humanistic business educational pedagogy will provide our students with a transcendental opportunity to reveal themselves and find a sustainable ontological purpose in their future business.

Humanistic business education rests on the basic assumption that the model of community reaches into ontology (i.e., assumptions about the nature of reality) and epistemology (i.e., how we know it) on which all education is built (Palmer, 1998). Understanding business as a holistic inter-dependent system, figuring out the right way to make the system flourish, and realizing oneself to become a responsible and creative leader will be at the core of RME.

While a series of pedagogical methodologies such as problem-based learning, flipped learning, case studies, pragmatic inquiries, value-based learning, and many others may be suggested, building a community of learning among the stakeholders (primarily between professors and students) in business education will be the essence of the right pedagogy of RME. The question of how to facilitate the community of learning as a uniquely vivifying dynamic is the key challenge for its orchestrator (i.e., professors).

Carefully selecting meaningful questions and inviting students to focused debates while stimulating their reflective and critical thinking is often suggested as a good approach to build a living learning community (McDonald, 2011). Good questions breed good open discussion, and discussions breed other good questions. Students engaging in the learning community will be provided with valuable opportunities of deep learning with valuable lessons. The role of professors then becomes facilitating and improvising the learning process and integrating the lesson to be shared. Professors who are conscious about and committed to the integral human development of students will generate creative and responsible ways to keep the learning community flourishing. 


\section{Institution}

Finally, institutions (i.e., business schools) themselves should become effective platforms to carry out the transformational process of paradigm change in management education. Unfortunately, however, skepticism has been so prevalent regarding the question of business schools being fit for that purpose. Business schools not only left the original commitment to raise business leaders as noble professionals unfulfilled (Khurana, 2011), but they are also now widely criticized (Amann et al., 2011; Buono, Carteron, \& Gitsham, 2012) and are even considered silent partners in corporate crimes in today's global economy (Swanson \& Frederick, 2003). Business schools around the globe are now facing enormous challenges to facilitate organizational change by embedding RME paradigm into their agenda.

Change management has been one of the most taught subjects in business schools today. Practicing what business professors preach, however, does not seem quite compelling in this case; whilst there are more than 13,000 business schools worldwide, as of May 2018, just over 700 (i.e., about 5 percent) had signed the UN PRME (Principles for RME), a global engagement platform for academic institutions supporting responsible principles in their business education. Despite many positive developments and innovations, corporate responsibility has not yet become mainstream in management education around the world (Exter, Grayson, \& Maher, 2013; Kell \& Haertle, 2011; Rasche \& Gilbert, 2015).

Successful change management of business schools itself is the critical third component of the transformational model. Based on the general management processes model of Fayol (1949) and change management model proposed by Kotter (1995) and others (Appelbaum, Habashy, Malo, \& Shafiq, 2012; Exter et al., 2013), I suggest the following list of factors to be followed in order to successfully complete the mission of institutional change towards responsible business schools.

\section{Planning for Change}

Setting a clear vision and mission and formulating creative and sustainable strategies for the business school will be the very first step toward the successful management of the transformational process. At this primary stage, agendas such as a) refurbishing the ontological mission of business school, b) establishing a sense of 'why' the paradigm shift is urgent (i.e., a sense of urgency), and c) developing and reviewing authentic business school strategies in teaching, research, and social service in tune with the mission.

\section{Organizing for Change}

Developing the organizational character of business schools will be critical in fitting with the nature of complexity and interdependence that is inherent in the new paradigm of business education. Through the effective designing of the governance of business school organizational capacity, facilitating each member's learning process will be most critical (Solitander, Fougère, \& Sobczak, 2011). Building a learning community and designing a high empowerment work system within business schools will be at the core of the organizing process towards successful change management. In addition, creating a guiding coalition will be a useful tactic in calling stakeholders' attention to the meaningfulness and urgency of the new paradigm in business education. Such multi-stakeholder group may consist of professors, students, alumni, business leaders, NGOs, and interested inter-governmental organizations such as the UN (Adams \& Petrella, 2010; Alcaraz, Marcinkowska, \& Thiruvattal, 2011; Godemann, Haertle, Herzig, \& Moon, 2014; Sobczak \& Mukhi, 2016; Solitander et al., 2011).

\section{Leading for Change}

Communicating the change vision and anchoring new approaches in the organizational culture of business schools will sustain each faculty member's motivation to continue in their commitment. At this stage, the self-effacing transformational leadership of business deans and the corresponding communitarian culture of the business school will be the most critical.

\section{Controlling (or Engaging) for Change}

While predicting and controlling has been the norm as the final stage of management processes during the industrial era, engaging every stakeholder in the continuous learning processes and remaining committed to the effectiveness and efficiency of the management processes has become the new rule in today's post-industrial era. Considering the level of complexity and uncertainty that is inherent in a paradigm change in the management education of business schools, the magic of the controlling mechanism may lie beyond developing the right KPI and a valid and reliable evaluation system. In addition, even a tactical solution such as generating short-term wins and consolidating gains as suggested by Kotter (1995) is only partial but not essential. A rather coherent culture that is rooted in the solid soil of a dedicated community of a purposeful business school will facilitate each member's engagement to stay on the right track in order to successfully carry on the noble mission of RME. Such group control will be a great complement to the old fashioned predict and monitoring mechanism in the genuine change processes. 


\section{Conclusion}

The discussion of the new paradigm in management education is no longer a question of choice, but rather of how it can be successfully practiced. UN PRME has been in existence for more than 10 years, and UN SDGs is in its fourth year, but the implementation of the new paradigm in business schools is still in its infancy. Business schools across the world are now at a crossroads of a breakthrough by self-realization with a new paradigm or a breakdown without being able to adapt to new environmental changes. This choice of business schools has become an important issue not only for the business continuity of management education but also for the future of sustainable humanity considering the enormous impact of business on the global community.

This study summarizes how to systematically approach this important issue of paradigm change in business schools. There has been a growing number of studies with a partial approach to this topic, but a systematic approach to integrating them has been a rarity. In this paper, I propose a transformational model that presents a balanced viewpoint for successful paradigm change in management education. I expect further and more detailed study of each component in the future.

In the end, the most fundamental problem in the change management processes of business education is the problem of change in the paradigm of professors themselves as educators for future business professionals. This leads to the question of how to bring about consciousness among the business professors of our time. It is time to reflect upon the ontological purpose of teaching as a business professor and to recuperate a sense of calling.

\section{References}

Adams, C., \& Petrella, L. (2010). Collaboration, connections and change: The UN global compact, the global reporting initiative, principles for responsible management education and the globally responsible leadership initiative. Sustainability Accounting, Management and Policy Journal, 1(2), 292-296.

Alcaraz, J. M., Marcinkowska, M. W., \& Thiruvattal, E. (2011). The UN-principles for responsible management education sharing (and evaluating) information on progress. Journal of Global Responsibility, 2(2), 151-169.

Amann, W., Pirson, M., Dierksmeier, C., Von Kimkowitz, E., \& Spitzeck, H. (2011). Business schools under fire: Humanistic management education as the way forward. Hampshire, England: Palgrave Macmillan.

Appelbaum, S. H., Habashy, S., Malo, J., \& Shafiq, H. (2012). Back to the future: Revisiting Kotter's 1996 change model. Journal of Management Development, 31(8), 764-782.

Bennis, W. G., \& O’Toole, J. (2005). How business schools lost their way. Harvard Business Review, 83(5), 96-104.

Buono, A., Carteron, J. C., \& Gitsham, M. (2012, June 11). Schools need to champion a sustainability mindset. Financial Times. Retrieved from https://www.ft.com/content/e748533a-aa41-11e18b9d-00144feabdc0

Carneiro, R., \& Draxler, A. (2008). Education for the 21st century: Lessons and challenges. European Journal of Education, 43(2), 149-160.

Community for Responsible Research in Business and Management. (2017). A vision for responsible research in business and management: Striving for useful and credible knowledge. Retrieved from https://rrbm.network/wp-content/uploads/2017/09/ White_Paper.pdf

Delors, J., Mufti, I. A., Amagi, I., Carneiro, R., Chung, F., Geremek, B., ... Nanzhao, Z. (1996). Learning: the treasure within: Report to UNESCO of the international commission on education for the twenty-first century. Paris, France: UNESCO.

Escudero, M. (2016). Transformational model for PRME implementation. New York, NC: UNGC.

Exter, N., Grayson, D., \& Maher, R. (2013). Facilitating organizational change for embedding sustainability into academia: A case study. Journal of Management Development, 32(3), 319-332.

Faure, E. (1972). Learning to be: The world of education today and tomorrow. Paris, France: UNESCO.

Freeman, R. E., \& Newkirk, D. (2011). Business school research: Some preliminary suggestions. In W. Amann, M. Pirson, W. Dierksmeier, E. Von Kimkowitz, \& H. Spitzeck (Eds.), Business schools under fire: Humanistic management education as the way forward (pp. 410-422). Hampshire, England: Palgrave Macmillan. Gioia, D. A. (2002). Business education's role in the crisis of corporate confidence. Academy of Management Executive, 16(3), 142144.

Godemann, J., Haertle, J., Herzig, C., \& Moon, J. (2014). United nations supported principles for responsible management education: Purpose, progress and prospects. Journal of Cleaner Production, 62(1), 16-23.

Gonin, M. (2007). Business research, self-fulfilling prophecy, and the inherent responsibility of scholars. Journal of Academic Ethics, 5(1), 33-58.

Ghoshal, S. (2005). Bad management theories are destroying good management practices. Academy of Management Learning and Education, 4(1), 75-91.

von Hayek, F. A. (1974). The pretence of knowledge. Retrieved from https://www.nobelprize.org/nobel_prizes/economic-sciences/ laureates/1974/hayek-lecture.html 
Fayol, H. (1949). General and industrial management. Pitman House, London, England: Pitman.

Kell, G., \& Haetle, J. (2011). UN global compact and responsible management education: The next decade. EFMD Global Focus, 5(2), 14-16.

Kelly, S., \& Nahser, R. (2014). Developing sustainable strategies: Foundations, method, and pedagogy. Journal of Business Ethics, 123(4), 631-644.

Khurana, R. (2011). From higher aims to hired hands: The social transformation of American business schools and the unfulfilled promise of management as a profession. In W. Amann, M. Pirson, C. Dierksmeier, E. Von Kimkowitz, \& H. Spitzeck (Eds.), Business schools under fire: Humanistic management education as the way forward (pp. 104-121). Hampshire, England: Palgrave Macmillan.

Kotter, J. P. (1995). Leading change: Why transformation efforts fail. Harvard Business Review, 73, 59-67.

Mackey, J., \& Sisodia, R. (2013). Conscious capitalism: Liberating the heroic spirit of business. Boston, MA: Harvard Business Review Press.

McDonald, R. (2011). What are the principles of a humanistic education? In W. Amann, M. Pirson, C. Dierksmeier, E. Von Kimkowitz, \& H. Spitzeck (Eds.), Business schools under fire: Humanistic management education as the way forward (pp. 130-146). Hampshire, England: Palgrave Macmillan.

Mintzberg, H. (2004). Managers not MBAs: A hard look at the soft practice of managing and management development (1st ed.). San Francisco, CA: Berrett-Koehler.

Palmer, P. J. (1998). The courage to teach: Exploring the inner landscape of a teacher's life. San Francisco, CA: Jessey-Bass.

Pirson, M., \& Malhotra, D. K. (2008). Unconventional insights for managing stakeholder trust. MIT Sloan Management Review, 49(4), 43-50.
Rasche, A., \& Gilbert, D. U. (2015). Decoupling responsible management education: Why business schools may not walk their talk. Journal of Management Inquiry, 24(3), 239-252.

Silver, S. (2012, June 18). Banking: Changed climate leads to revamped curriculums. Financial Times. Retrieved from http:// www.ft.com/intl/cms/s/2/29fad844-aa59-11e1-899d-00144feabdc0.html\#axzz1zZv GumtI

Sobczak, A., \& Mukhi, U. (2016). The role of UN principles for responsible management education in stimulating organizational learning for global responsibility within business schools: An interview with Jonas Haertle. Journal of Management Inquiry, 25(4), 431-437.

Solitander, N., Fougère, M., \& Sobczak, A. (2011). We are the champions: Organizational learning and change for responsible management education. Journal of Management Education, 36(3), 337-363.

Spitzeck, H. (2011). A developmental model for humanistic management education. In W. Amann, M. Pirson, C. Dierksmeier, E. Von Kimkowitz, \& H. Spitzeck (Eds.), Business schools under fire: Humanistic management education as the way forward (pp. 410422). Hampshire, England: Palgrave Macmillan.

Swanson, D. L., \& Frederick, W. C. (2003). Are business schools silent partners in corporate crime? Journal of Corporate Citizenship, 9(1), 24-27.

Yang, B., Ding, D., Umez, M., Siegenthaler, C. P., Okamatsu, A., \& Park, Y. S. (2011). Humanistic management education in Asia: Responsible management education of Asian business schools for the changing era. In W. Amann, M. Pirson, C. Dierksmeier, E. Von Kimkowitz, \& H. Spitzeck (Eds.), Business schools under fire: Humanistic management education as the way forward (pp. 323339). Hampshire, England: Palgrave Macmillan. 